\title{
Effect of Balance Use of Fertilizers on Performance of Wheat Under Arid Climatic Condition
}

Malik Muhammad Yousaf ${ }^{1}$ Muhammad Mohsin Raza' ${ }^{*}$, Mumtaz Hussain ${ }^{1}$, Muhammad Jahangir Shah $^{1}$,
Bashir Ahmad ${ }^{1}$, Rao Wali Muhammad ${ }^{1}$, Sami Ullah $^{2}$, Adeel Abbas $^{3}$, Ijaz Ahmed $^{4}$ and Muhammad Zeshan $^{5}$

${ }^{1}$ Pakistan Agricultural Research Council Arid Zone Research Institute Bahawalpur 63100, Pakistan; ${ }^{2}$ Institute of Agricultural Resources and Regional Planning Chinese Academy Agriculture sciences Beijing100081, China; ${ }^{3}$ Institute of Environment and Ecology, School of Environment and Safety Engineering, Jiangsu University, Zhenjiang 212013, PR China; ${ }^{4}$ Ecotoxicology Research Program National Agricultural Research Centre Islamabad 44000, Pakistan; ${ }^{5}$ National institute for Genomic and Advanced Biotechnology, National Agricultural Research Centre Islamabad 44000, Pakistan.

Abstract | Nutrients play a key role in crop productivity. A field trial was conducted to evaluate the addition of macro and micronutrients on wheat growth and productivity. The experiment comprised of 10 treatments. The results showed that compared with control, addition of nutrients significantly increased plant height and the highest plant height $(86.5 \mathrm{~cm})$ was observed at $86: 58: 62.5 \mathrm{~kg}$ NPK$/$ ha treatment. Maximum tillers/plant (3.1), spikelet's/plant (2.9), and spike length $(8.9 \mathrm{~cm})$ was found in $86-58-62.5-3 \mathrm{~kg} \mathrm{NPK}+\mathrm{Zn} / \mathrm{ha}$ treatment. Furthermore, highest grains/spike (83.4), 1000 grain weight $(4.3 \mathrm{~g})$, and yield $(6381 \mathrm{~kg} / \mathrm{ha})$ was found in 86-58-62.5-3 kg NPK $+\mathrm{Br} / \mathrm{ha}$ treatment. Our results demonstrated that compared with sole addition of macronutrients, addition of both macro and micronutrients together practices that will make farmer wheat yield higher and more profitable.

Received | February 10, 2020; Accepted | August 20, 2020; Published | October 08, 2020

*Correspondence | Muhammad Mohsin Raza, Pakistan Agricultural Research Council Arid Zone Research Institute Bahawalpur 63100, Pakistan; Email: mohsinraza_5@yahoo.com

Citation | Yousaf, M.M., M.M. Raza, M. Hussain, M.J. Shah, B. Ahmad, R.W. Muhammad, S. Ullah, A. Abbas, I. Ahmed and M. Zeshan. 2020. Effect of balance use of fertilizers on performance of wheat under arid climatic condition. Pakistan Journal of Agricultural Research, 33(4): 778-782. DOI | http://dx.doi.org/10.17582/journal.pjar/2020/33.4.778.782

Keywords | Balance, Use, Fertilizer, Wheat, Yield

\section{Introduction}

W Theat is a major source of plant based nutrition for human and daily dietary needs. An assessment demonstrates that, Pakistan produces reduced yield as compared with other wheatproducing countries (China, India, USA Russia and France) (Hussain et al., 2006). Scanty use of fertilizers poor seed quality, water logging, high input prices, lack of irrigation water, lower farmer education about the latest techniques in crop production beside imbalance use of chemical and organic fertilizers are some of the major factors in low wheat production (Ali et al.,
2018). Specific nutrients are categorically important for plant growth, yield and their life cycle (White et al., 2012). Two types of nutrients, micro ( $\mathrm{Zn}, \mathrm{Cu}, \mathrm{B}$, $\mathrm{Fe}$, and $\mathrm{Mn})$ and macronutrients $(\mathrm{N}, \mathrm{P}$ and $\mathrm{K})$ are essential for plants to perform their own functions in growth and development. The farmer mostly use macronutrients $(\mathrm{N}, \mathrm{P}$, and $\mathrm{K}$ ) are an important and recommended for high wheat yield (Watanabe et al., 2007). While, the use of micronutrients with macronutrients is highly effective for wheat crop yield (Wang et al., 2016). Micronutrients are needed in trace amount but adequate supply played an important role in yield improvements and positively effects on 
cell physiology and on yield as well (Dimkpa and Bindraban et al., 2016).

In Pakistan, wheat is severely affected by $\mathrm{Zn}$ deficiency. Many researchers recognized Zinc deficiency in Pakistan in different cereals crops including wheat (Chatthaet al., 2017; Rafique et al., 2006). Latest survey reported $70 \% \mathrm{Zn}$ is deficient in Pakistani soils. $\mathrm{Zn}$ deficiency is one of the third serious nutrients for wheat crops after Nitrogen $(\mathrm{N})$ and phosphorus $(\mathrm{P})$ (Amanullah and Inamullah, 2016; Akhtar, 2013).

Due to our less yield potential in Pakistan it is very important to design such a study which will address the issue of less yield potential (Agric. Stat. Pakistan, 2000-2001). We conduct an experiment to evaluate the effect of macronutrients on wheat yield and explore additive effects of macronutrients (NPK) with micronutrients.

\section{Materials and Methods}

The experiment was conducted at research farm of (PARC) Arid Zone Research Institute in, Bahawalpur, on November $27^{\text {th }} 2018$. Seeds of wheat cultivar Galaxy 2013 acquired from the Regional Agricultural Research Institute Bahawalpur and sown at rate of $120 \mathrm{~kg} \mathrm{ha}^{-1}$ in a $22.5 \mathrm{~cm}$ spaced row. Detailed physicochemical properties of soil are given in (Table 1) a randomized complete block design, with three replications were employed as an experimental design. The net plot size was maintained at $1.8 \times 6.0 \mathrm{~m}$, the experiment comprised 10 treatments as followed:

$\begin{array}{ll}\text { Control } & \text { Value } \\ \text { T1 } & \text { 86kg N/ha } \\ \text { T2 } & 58 \mathrm{~kg} \mathrm{P} / \mathrm{ha} \\ \text { T3 } & 62.5 \mathrm{~kg} \mathrm{~K} / \mathrm{ha} \\ \text { T4 } & 86 ; 58 \mathrm{kgNP} / \mathrm{ha} \\ \text { T5 } & 86 ; 62.5 \mathrm{~kg} \mathrm{NK} / \mathrm{ha} \\ \text { T6 } & 58 ; 62.5 \mathrm{~kg} \mathrm{PK} / \mathrm{ha} \\ \text { T7 } & 86 ; 58 ; 62.5 \mathrm{kgNPK} / \mathrm{ha} \\ \text { T8 } & 86 ; 58 ; 62.5 ; 3 \mathrm{kgNPK} \mathrm{Zn} / \mathrm{ha} \\ \text { T9 } & 86 ; 58 ; 62.5 ; 3 \mathrm{kgNPKBr} / \mathrm{ha}\end{array}$

Whole of $\mathrm{P}, \mathrm{K}$ and one third of $\mathrm{N}$ was applied as basal dose. The remaining of $\mathrm{N}$ applied with $1^{\text {st }}$ and $2^{\text {nd }}$ irrigation four irrigation (3-acer inch each) were applied from sowing to harvesting. Crop was harvested on April, 15 $5^{\text {th }}$ 2019. The Statistical analysis was carried out with SAS version 8.0 for windows. For each variable measured the data was analyzed by one way ANOVA and treatment means were separated by LSD method at 5\% probability level.

\section{Table 1: Physicochemical analysis of experimental soil.}

$\begin{array}{ll}\text { Characteristic } & \text { Value } \\ \text { Texture } & \text { Sandy loam } \\ \mathrm{PH} & 8.10 \\ \mathrm{Ec} & 0.35 \mathrm{dsm}^{-1} \\ \text { Exchangeable } \mathrm{Na} & 0.20 \mathrm{mmolc}^{100 \mathrm{~g}^{-1}} \\ \text { Organic matter } & 0.95 \% \\ \text { Nitrogen } & 0.07 \% \\ \text { Phosphorus } & 5.00 \mathrm{ppm} \\ \text { Potassium } & 177.0 \mathrm{ppm} \\ \text { Zinc } & 0.80 \mathrm{ppm} \\ \text { Boron } & 0.78 \mathrm{ppm} \\ \text { Iron } & 6.75 \mathrm{ppm}\end{array}$

\section{Results and Discussion}

\section{Plant height}

The results showed that addition of various macro and micro nutrients have profound impact on plant height (Table 2). Maximum plant height $(86.5 \mathrm{~cm})$ was found in NPK followed by NPK $+\mathrm{Zn}(86.1 \mathrm{~cm})$. Nitrogen and $\mathrm{P}$ addition resulted in significantly higher plant height $(84.3 \mathrm{~cm})$ compared with $\mathrm{NK}$ $(81.4 \mathrm{~cm})$ and PK $(72.4 \mathrm{~cm})$ treatments. Whereas the Lowest plant height was recorded in control $(68.3 \mathrm{~cm})$. Hussain et al. (2002) showed that NPK addition significantly increased plant height. Other researchers demonstrated that addition of macronutrients coupled with micronutrients such as $\mathrm{Zn}$ and $\mathrm{Br}$ significantly increased plant height (Nadim et al., 2012; Anjum et al., 2019).

\section{Tillers/plant}

Addition of various combinations of macro and micro nutrients significantly affected tillers/plant. Highest tillers/plant was observed in $\mathrm{NPK}+\mathrm{Zn}$ (3.1) and $\mathrm{NPK}+\mathrm{Br}$ (3.1) treatments respectively followed by NPK (3.0) treatment. There was no significant difference in tillers/plant in $\mathrm{NPK}+\mathrm{Zn}, \mathrm{NPK}+\mathrm{Br}$, and NPK treatments. PK treatment produced higher tiller/plant (2.5) as compared to NP (2.2) and NK (1.9) treatments. Lowest tillers/plant was found in control (1.3). The results of this study are compatible with those of (Hussain et al., 2002), who indicated that NPK addition significantly increased tillers/plant. 
Table 2: Effects of macro and micronutrients on wheat productivity.

$\begin{array}{llllllll}\text { Treatments } & \text { PH } & \text { TP } & \text { SP } & \text { SL } & \text { GS } & \mathbf{1 0 0 0} \mathbf{G W} & \text { Y } \\ \text { Control } & 68.3 \mathrm{~d} & 1.3 \mathrm{f} & 1.2 \mathrm{~g} & 6.6 \mathrm{~h} & 35.5 \mathrm{e} & 2.6 \mathrm{e} & 2435.0 \mathrm{~g} \\ 86 \mathrm{~kg} \mathrm{~N} / \mathrm{ha} & 80.8 \mathrm{~b} & 2.0 \mathrm{de} & 1.5 \mathrm{f} & 7.2 \mathrm{~g} & 68.3 \mathrm{~d} & 3.1 \mathrm{~d} & 5001.5 \mathrm{e} \\ 58 \mathrm{~kg} \mathrm{P} / \mathrm{ha} & 75.3 \mathrm{c} & 2.1 \mathrm{~cd} & 1.7 \mathrm{e} & 8.1 \mathrm{e} & 77.2 \mathrm{abc} & 3.9 \mathrm{bc} & 5417.3 \mathrm{c} \\ 62.5 \mathrm{~kg} \mathrm{~K} / \mathrm{ha} & 69.8 \mathrm{~d} & 2.2 \mathrm{c} & 1.8 \mathrm{de} & 7.6 \mathrm{f} & 74.0 \mathrm{~cd} & 3.7 \mathrm{c} & 4634.6 \mathrm{f} \\ 86-58 \mathrm{~kg} \mathrm{NP} / \mathrm{ha} & 84.3 \mathrm{ab} & 2.2 \mathrm{c} & 2.1 \mathrm{c} & 7.7 \mathrm{f} & 81.7 \mathrm{ab} & 3.8 \mathrm{c} & 5733.5 \mathrm{~b} \\ 86-62.5 \mathrm{~kg} \mathrm{NK} / \mathrm{ha} & 81.4 \mathrm{~b} & 1.9 \mathrm{e} & 1.8 \mathrm{~d} & 7.3 \mathrm{~g} & 72.4 \mathrm{~cd} & 3.1 \mathrm{~d} & 5201.1 \mathrm{~d} \\ 58-62.5 \mathrm{~kg} \mathrm{PK} / \mathrm{ha} & 72.4 \mathrm{~cd} & 2.5 \mathrm{~b} & 2.1 \mathrm{c} & 8.6 \mathrm{~b} & 74.6 \mathrm{bcd} & 3.8 \mathrm{c} & 5641.8 \mathrm{~b} \\ 86: 58: 62.5 \mathrm{~kg} \mathrm{NPK} / \mathrm{ha} & 86.5 \mathrm{a} & 3.0 \mathrm{a} & 2.5 \mathrm{~b} & 8.4 \mathrm{c} & 78.1 \mathrm{abc} & 4.0 \mathrm{bc} & 6332.1 \mathrm{a} \\ 86-58-62.5-3 \mathrm{~kg} \mathrm{NPK} \mathrm{Zn/ha} & 86.1 \mathrm{a} & 3.1 \mathrm{a} & 2.9 \mathrm{a} & 8.9 \mathrm{a} & 76.9 \mathrm{abc} & 4.1 \mathrm{ab} & 6336.1 \mathrm{a} \\ 86-58-62.5-3 \mathrm{~kg} \mathrm{NPKBr} / \mathrm{ha} & 84.1 \mathrm{ab} & 3.1 \mathrm{a} & 2.9 \mathrm{a} & 8.3 \mathrm{~d} & 83.4 \mathrm{a} & 4.3 \mathrm{a} & 6381.3 \mathrm{a}\end{array}$

Values with different letters in a column differ significantly as determined by fisher's LSD at $P<0.05$.

Note: PH: plant height; TP: tillers/plant; SP: spikelet's/plant; SL: spike length; GS: grains/spike; 1000 GW: 1000 grain weight; Y: yield.

Furthermore, a study demonstrated that addition of micronutrients such as $\mathrm{Zn}$ and $\mathrm{Br}$ significantly increased tiller/plant (Nadim et al., 2012; Anjum et al., 2019).

\section{Spike length}

The results presented in (Table 2) revealed that inorganic fertilization significantly affected spike length. Statistically highest spike length was observed in $\mathrm{NPK}+\mathrm{Zn}(8.9 \mathrm{~cm})$ treatment followed by $\mathrm{NK}(8.6 \mathrm{~cm}), \mathrm{NPK}(8.4 \mathrm{~cm})$, and $\mathrm{NPK}+\mathrm{Br}(8.3 \mathrm{~cm})$ treatments respectively. $\mathrm{P}$ addition significantly increased spike length $(8.1 \mathrm{~cm})$ over $\mathrm{K}(7.6 \mathrm{~cm})$ and $\mathrm{P}$ $(7.2 \mathrm{~cm})$ addition. Minimum spike length was found in control $(6.6 \mathrm{~cm})$. Our results were consistent with those of (Firdous et al., 2018) showed that NPK fertilization along with $\mathrm{Zn}$ increased spike length.

\section{Grains/spike}

According to the results presented in (Table 2) exogenous addition of macro and micronutrients significantly impacted grains/spike. Highest of grains/ spike were noted in $\mathrm{NPK}+\mathrm{Br}$ (83.4) followed by $\mathrm{NP}$ (81.7) treatment. In comparison with $\mathrm{NPK}+\mathrm{Zn}$ treatment (76.9) higher number of grains/spike was found in NPK treatment (78.1) but there was no significant difference found between them. Lowest grains/spike was recorded in control treatment (35.5). Our results were in line with those of (Hussain et al., 2002), who showed that NPK addition significantly increased grains/spike as compared to control. Another study showed that addition of micronutrients such as $\mathrm{Zn}$ and $\mathrm{Br}$ along with macronutrients significantly increased wheat number of grains/spike (Nadim et al., 2012).

\section{0 grain weight}

The results showed that various combination of both macro and micronutrients addition significantly impacted 1000 grain weight (Table 2). Maximum 1000 grain was observed in $\mathrm{NPK}+\mathrm{Br}$ treatment $(4.3 \mathrm{gm})$ followed by $\mathrm{NPK}+\mathrm{Zn}(4.1 \mathrm{gm})$ and NPK $(4.0 \mathrm{gm})$ treatments. Lowest number of 1000 grain weight was recorded in control $(2.6 \mathrm{gm})$. Studies conducted in Pakistan demonstrated that NPK addition significantly increased wheat productivity (Hussain et al., 2002). A research finding showed that addition of NPK along with $\mathrm{Br}$ significantly increased 1000 grain weight. A study (Nadim et al., 2012) and (Firdous et al., 2018) claimed that $\mathrm{Zn}$ addition significantly increased 1000 grain weight.

\section{Grain yield $\mathrm{Kg} / \mathrm{ha}$}

Addition of macro and micronutrients significantly impacted grain yield. Maximum grain yield was observed in $\mathrm{NPK}+\mathrm{Br}$ (6381) treatment followed by $\mathrm{NPK}+\mathrm{Zn}$ (6336) and NPK (6332) treatments. However, no significant difference was found among these three treatments. NP (5733) and PK (5641) treatments had substantial higher grain yield over NK (5201). Furthermore, it was observed that addition of $\mathrm{P}$ (5417) produced maximum grain yield compared with N (50001) and K (4634) addition. Lowest grain yield was recorded in control (2435). Our results were in agreement with those of (Hussain et al., 2002), who stated that NPK addition significantly increased grain yield. A study by Anjum et al. (2019) showed that addition of NPK along with $\mathrm{Br}$ successfully increased wheat yield. In addition, NPK along with $\mathrm{Zn}$ input significantly increased wheat yield (Nadim et al., 2012; Firdous et al., 2018). 
Novelty Statement

To the best of our knowledge this is the first study conducted on balance use of fertilizer on wheat under arid conditions.

\section{Author's Contribution}

Malik Muhammad Yousaf conceived idea and techniocal guidance. Muhammad Mohsin Raza technical input at every step and over all write up of paper. Mumtaz Hussain, Muhammad Jahangir Shah, Bashir Ahmad and Rao Wali Muhammad date collection. Samiullah data SPSS analysis. Adeel Abbas and Ijaz Ahmad technical assistants. Muhammad Zeshan rferences.

\section{Conflict of interest}

The authors have declared no conflict of interest.

\section{References}

Ali, B., A. Ridzwan, A. Halim, M. Fazui and S.S. Zahara. 2018. Impact of organic and inorganicfertilizers on the yield and quality of silage corn intercropped with soybean. Peer J., pp. 5280.

Amanullah and Inamullah. 2016. Residual phosphorus and zinc influence wheat productivity under rice wheat cropping system. Springer Plus, 5(1): 255. https://doi. org/10.1186/s40064-016-1907-0

Akhtar, S., 2013. Zinc status in South Asian Populations. J. Health Popult. Nutr., 31(2): 139149. https://doi.org/10.3329/jhpn.v31i2.16378 Anjum, S.A., S. Ullah, M.M. Raza, M. Raza, M. Abbas, I. Ahmad, M.M. Yousaf, M. Zeshan, A. Abbas and M.A. Noor. 2019. Exogenous supply of boron at various growth stages improved wheat yield. Pak. J. Agric. Res., 32(3): 422-427. https://doi.org/10.17582/journal. pjar/2019/32.3.422.427

Agricultural Statistics of Pakistan, 2000-2001. Ministry of food, agriculture and livestock (MINFAL). Economic Wing, Islamabad, Pakistan.

Chattha, M.U., M.U. Hassan, I. Khan, M.B. Chattha, A. Mahmood, M.U. Chattha and S. Khan. 2017. Biofortification of wheat cultivars to combat zinc deficiency. Front. Plant Sci., pp. 8. https://doi.org/10.3389/fpls.2017.00281
Dimkpa, C.O. and P.S. Bindraban. 2016. Fortification of micronutrients for efficient agronomic production. Rev. Agron. Sustainable Dev., 36(1). https://doi.org/10.1007/s13593015-0346-6

Firdous, S., B. Agarwal and V. Chhabra. 2018. Zinc-fertilization effects on wheat yield and yield components. J. Pharm. Phyto., 7(2): 34973499

Hussain, M.I., S.H. Shah, S. Hussain and K. Iqbal. 2002. Growth, yield and quality response of three wheat (Triticum aestioum $\mathrm{L}$.) varieties to different levels of N, P and K.I. J. Agric. Biol., 4(2): 362-364.

Nadim, M., I. Awan, M. Baloch, E. Khan, K. Naveed and M. Khan. 2012. Response of wheat (Triticum aestivum L.) to different micronutrients and their application methods. J. Anim. Plant Sci., 22(1): 113-119.

Hussain,I., M.A.Khan and E.A. Khan.2006. Bread wheat varieties as influenced by different nitrogen levels. J. Zhej. Univ. Sci., 7(1): 70-78. https://doi.org/10.1631/jzus.2006.B0070

Mahboobeh, Z., A.S. Morteza, T. Mryam and S.A. Reza. 2014. Effects of organic and chemical fertilizers on quantitative and qualitative characteristics of peppermint (Menthapiperita L.). I. J. Agric. Cro. Sci., (IJACS) .7(1): 237-244.

Rafique, E., A. Rashid, J. Ryan and A.U. Bhatti. 2006.ZincdeficiencyinrainfedwheatinPakistan: Magnitude, spatial variability, management, and plant analysis diagnostic norms. Commun. Soil Sci. Plant Anal., 37(1-2): 181-197. https:// doi.org/10.1080/00103620500403176

White, P.J. and P.H. Brown. 2010. Plant nutrition for sustainable development and global health. Ann. Bot., 105(7): 1073-1080. https://doi. org/10.1093/aob/mcq085

White, P.J., M.R. Broadley and P.J. Gregory. 2012. Managing the nutrition of plants and people. J. Appl. Environ. Soil Sci., 7(1): 1-13. https://doi.org/10.1097/00010694193401000-00001

Watanabe, T., M.R. Broadley, S. Jansen, P.J. White, J. Takada, K. Satake and M. Osaki. 2007. Evolutionary control of leaf element composition in plants. New Phytol., 174(3): 516-523. https://doi.org/10.1111/j.14698137.2007.02078.x

Wang, F., Z. Wang, C. Kou, Z. Ma and D. Zhao. 
2016. Responses of Wheat Yield, Macro and Micro-nutrients, and heavy metals in soil and wheat following the application of manure and compost on the North China plain. PLoS Org., 11(1): e0146453. https://doi.org/10.1371/ journal.pone. 0146453 